\title{
Tree Morphometric Relationships and Dynamic Elasticity Properties in Tropical Rain Tree (Samanea saman Jacq. Merr)
}

\author{
Lina Karlinasari ${ }^{1, *(\mathbb{D}, \text { Ulfa Adzkia }}{ }^{1}$, Tiara Puspitasari ${ }^{1}$, Dodi Nandika ${ }^{1}$, Naresworo Nugroho ${ }^{1}(\mathbb{D}$, \\ Utami Dyah Syafitri ${ }^{2}$ and Iskandar Z. Siregar ${ }^{3}$
}

1 Department of Forest Products, Faculty of Forestry and Environment, IPB University, Jl. Lingkar Akademik, Darmaga, Bogor 16680, West Java, Indonesia; ulfa23adzkia@apps.ipb.ac.id (U.A.); tiara_asep31@apps.ipb.ac.id (T.P.); nandikadodi@gmail.com (D.N.); nares@apps.ipb.ac.id (N.N.)

2 Department of Statistic, Faculty of Mathematics and Natural Science, IPB University, Jl. Lingkar Akademik, Darmaga, Bogor 16680, West Java, Indonesia; utamids@apps.ipb.ac.id

3 Department of Silviculture, Faculty of Forestry and Environment, IPB University, Jl. Lingkar Akademik, Darmaga, Bogor 16680, West Java, Indonesia; siregar@apps.ipb.ac.id

* Correspondence: karlinasari@apps.ipb.ac.id

check for updates

Citation: Karlinasari, L.; Adzkia, U.; Puspitasari, T.; Nandika, D.; Nugroho, N.; Syafitri, U.D.; Siregar, I.Z. Tree Morphometric Relationships and Dynamic Elasticity Properties in Tropical Rain Tree (Samanea saman Jacq. Merr). Forests 2021, 12, 1711. https://doi.org/ $10.3390 / \mathrm{f} 12121711$

Academic Editors: Brian Kane and Timothy A. Martin

Received: 13 September 2021

Accepted: 4 December 2021

Published: 6 December 2021

Publisher's Note: MDPI stays neutral with regard to jurisdictional claims in published maps and institutional affiliations.

Copyright: (c) 2021 by the authors. Licensee MDPI, Basel, Switzerland. This article is an open access article distributed under the terms and conditions of the Creative Commons Attribution (CC BY) license (https:// creativecommons.org/licenses/by/ $4.0 /)$.

\begin{abstract}
Rain tree (Samanea saman) is a dominant species commonly planted as a shade tree in urban landscapes in the tropics, including in Indonesia. This species is also targeted for routine inspection and monitoring within tree management systems. Management should particularly focus on tree health through assessment of tree growth conditions as well as tree stability. However, baseline information on the relationships of many key characteristics for the rain tree (e.g., growth, morphometrics, and biomechanics) is lacking. Therefore, an investigation was carried out to determine the relationship of morphometric parameters to tree growth, which included use of an acoustic tool to assess the elasticity of the tree stem. Fifty rain trees were selected for data collection and evaluated using stress wave velocity tools and visual morphometrics assessment. The results demonstrated that, in general, the trees had good vigor and stability. Statistical analysis showed a strong relationship between tree growth parameters and selected morphometric characteristics. The use of a nondestructive acoustic-based instrument enabled determining the modulus of elasticity, which provided equivalent results with the elasticity value obtained through a common method for determining tree stability. Only live crown ratio and tree slenderness parameters had a relationship with the dynamic modulus of elasticity. These results offer a means of measurement that is simpler, less expensive, and faster than current methods, although further testing is needed for different tree species and growth sites.
\end{abstract}

Keywords: tree stability; modulus of elasticity; tree inspection; biomechanics; stress wave velocity

\section{Introduction}

Rain tree (Samanea saman Jacq. Merr), a species of the Fabaceae family, is easily recognized by its characteristic umbrella-shaped crown with a typically broad and domed form. The horizontal crown spread is greater than the height when the tree is grown in spacious and open settings. Commonly planted as an ornamental tree in public places, rain trees are intolerant of shade and require abundant light to grow well.

The trees can reach 15-25 $\mathrm{m}$ tall with a broad crown (typically $30 \mathrm{~m}$ in diameter) and can live for about 80-100 years [1]. The rain tree is adapted to waterlogged environmental conditions, and it tolerates soils with low nutrients. It is considered a fast-growing tree in suboptimal conditions. The trees can grow in paved areas, into foundations, or on shallow bedrock, despite restricted root growth. The extreme conditions make the species vulnerable to being windthrown given the shallow root system [1]. In addition, the roots can emerge above the soil level as the tree matures.

Indonesia, similar to neighboring countries such as Singapore and Malaysia, cultivates rain trees as tropical urban trees [2]. The trees have become an important species for 
roadsides and are very well known as shade trees because of their excellent canopy structure that accords with site requirements in urban landscapes. However, various external stress factors pose potential risks to the trees' health and vitality, especially as a result of infrastructure, drainage, and increased road widening. Tree failure could occur due to stem failure or to the whole tree overturning [3]. Brüchert et al. [4] reported that tree stability depends on morphological characteristics such as trunk condition, canopy or crown, tree architecture, and root architecture, and these parameters are especially important in built environments [5].

Due to the importance of trees in the urban environment landscape, investigating tree characteristics is critical to enable ecosystem services based on adequate planning for the canopy size and the direction of growth of a given tree [6]. Tree growth and morphometric studies are essential for knowing the dynamics of tree shape and behavior [7]. Bobrowski and Biondi [8] affirmed that morphometric indices act as tools that help in afforestation planning and management of trees by providing useful knowledge on the characteristics of each species. For example, tree architecture, as one parameter of tree morphometry, is determined by the genotypic factors underlying the development of the buds and branches of each species. The trees in the urban environment can be phenotypically influenced by the anthropic environment and may develop differently from those under open cultivation conditions or in forest areas. Pruning activities, people and vehicle movement, and the construction of buildings and roads may place pressure on trees [9]. This pressure is related to the ability of trees to have a functional trade-off in balancing the crown size and shape with wind resistance [10]. Above all else, tree management must consider the safety of people and the protection of infrastructure, especially given the proximity of the trees to roads.

Tree stability is an important aspect to be considered for susceptibility to wind damage and a tree's capacity to withstand its own weight. Consequently, the mechanical stability of the trees constitutes one of the fundamental factors in management. Some variables that must be taken into account for tree stability are wind characteristics (e.g., speed, duration, and gustiness), crown characteristics (e.g., crown size, density, and mass), tree height, tip displacement, stem characteristics (e.g., wood strength and stem elasticity), soil and root characteristics (e.g., root-soil weight, soil type, soil shear strength, and root strength), and topography of the site [11]. Many methods can be used to evaluate mechanisms of tree stability, such as the tree pulling test, tree swaying, and wind tunnel [11-13]. In particular, the pulling test is a static test that examines tree loading and trunk fraction resistance related to root strength. Previous research by $[13,14]$ using the pulling test on rain trees showed that the depth of root plates and structural soil conditions were significant factors in tree failure through uprooting without any stem fracture. Soil characteristics also influence the growth performance of the rain tree [2], with compact structural soil leading to better growth performance in the urban environment compared with pavement and grass areas.

Trees grow in response to their local environment in ways that cannot be easily modelled or fully understood without in-depth examination. The challenges are particularly associated with trees being susceptible to dramatic changes in abiotic and biotic conditions such as rainfall and epiphyte load. Trees respond to static (self-weight) and dynamic (wind) loadings. Niklas [15] reported that tree growth patterns can compensate for increased load, which is especially relevant for tropical trees because they tend to have greater epiphyte loads than trees growing in most other ecosystem types. Stem elasticity is another important parameter in studying tree stability. Niklas [16] noted that the mechanical properties of elastic modulus (E) indicate the ability of the tree to resist bending. Meanwhile, flexural stiffness (EI) of the stem reflects a material characteristic as a function of elasticity (E) and stem geometry (second moment of area, I). Further information on the E value of trees is important because understanding of the mechanical properties of fresh wood in terms of the mechanical design of trees is still limited [16]. A previous study by [17] and [18] demonstrated a pulling test on standing trees to calculate living stem elasticity based on the structural Young's modulus. The pulling testing needs complementary tools such as a 
strain gauge and LVDT (Linear Variable Differential Transformer) transducer to measure displacement due to the loading condition caused by pulling. Our study measured E of the stem of live trees, using a simple acoustic tool based on stress wave velocity as reported by [19-22]. Therefore, a study on tree stability and failure is necessary, particularly in terms of the tree morphometric and biomechanical characteristics, which have been little studied for this particular species. The objectives of our study were i) to analyze morphometric parameters and tree growth, ii) to evaluate the elasticity of tree stems based on the acoustic tool, and iii) to find out how morphometric parameters and tree growth are related to tree stem elasticity.

\section{Methodology}

Fifty rain trees (Samanea saman Jacq. Merr), a species that grows across IPB University Darmaga Campus, were purposively selected for this study (Figure 1). The Darmaga Campus has an area of 256.97 ha and is located at around latitude $6^{\circ} 33^{\prime} 566^{\prime \prime} \mathrm{S}$ to longitude $106^{\circ} 43^{\prime} 877^{\prime \prime}$ E. The soil type in the area is Latosol with clay $[23,24]$. Since there was no specific information with respect to tree age and history of crown pruning treatments, the main criterion for selecting trees for the study was based on diameter at breast height (dbh) exceeding $30 \mathrm{~cm}$ (Figure 2).

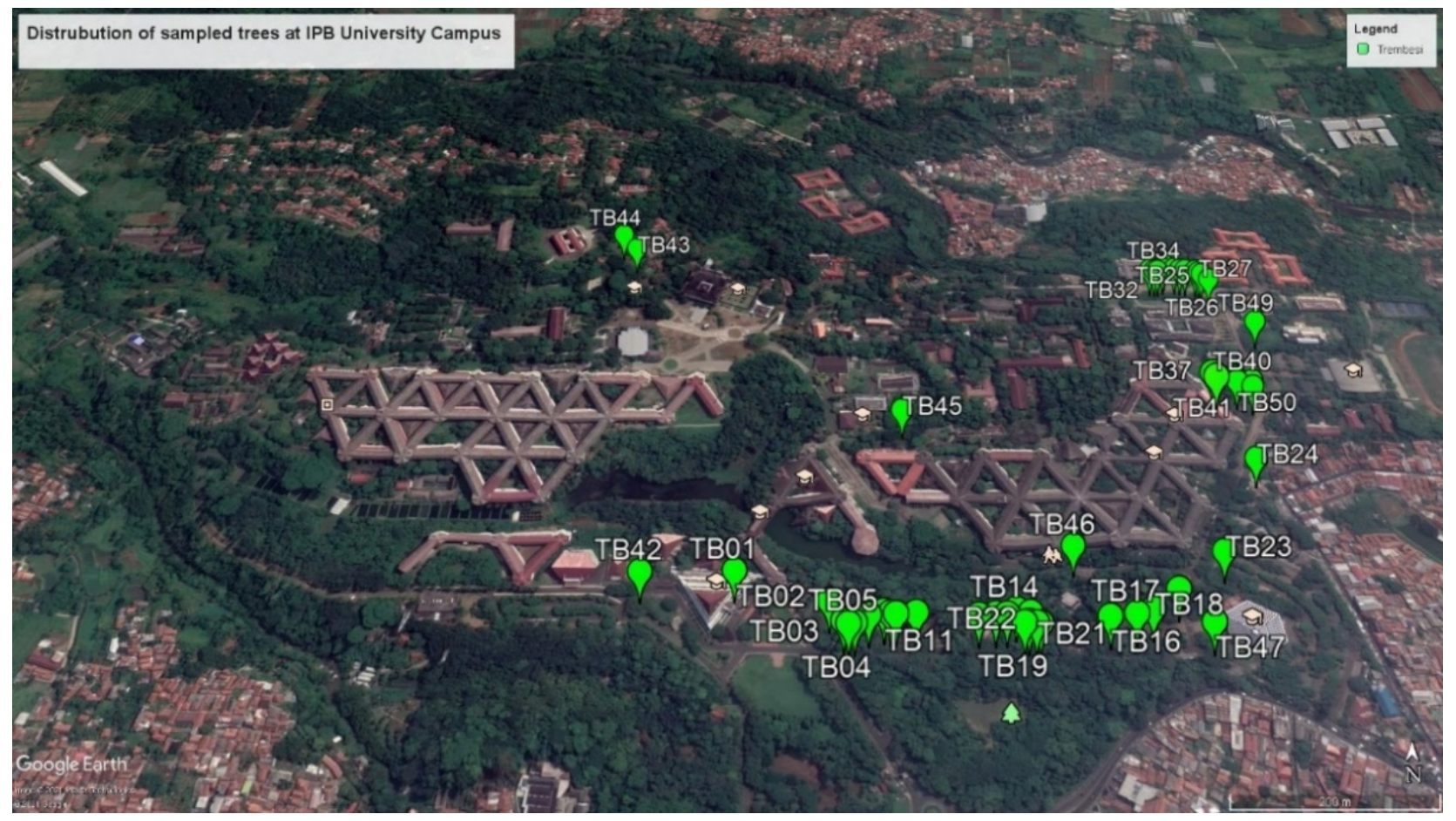

Figure 1. The location of rain tree samples.

The tree morphometric characteristics were analyzed based on parameters recommended by [6,25-28]. The stem dbh $(1.3 \mathrm{~m}-\mathrm{dbh}(d))$ was measured with a girth tape. Tree height $(h)$ and crown length $\left(h_{c r}\right)$ were measured using a Haga hypsometer. Crown length $\left(h_{c r}\right)$ was determined from tree height $(h)$ minus the height of the first living branch. Live crown ratio $(L C R)$ was calculated by dividing the crown length by the tree height $\left(L C R=h_{c r} / h\right)$. The parameter of slenderness $(S)$ was calculated as the ratio of tree height to $\mathrm{dbh}(S=h / d)$. Mean crown diameter $(D C R)$ was calculated as the average of the longest and shortest crown diameters measured in eight sub-cardinal directions referring to [6]. The horizontal projection of the crown $(P C R)$ or crown projection area was determined by the formula $P C R=\left(D C R^{2} x \pi\right) / 4$. 


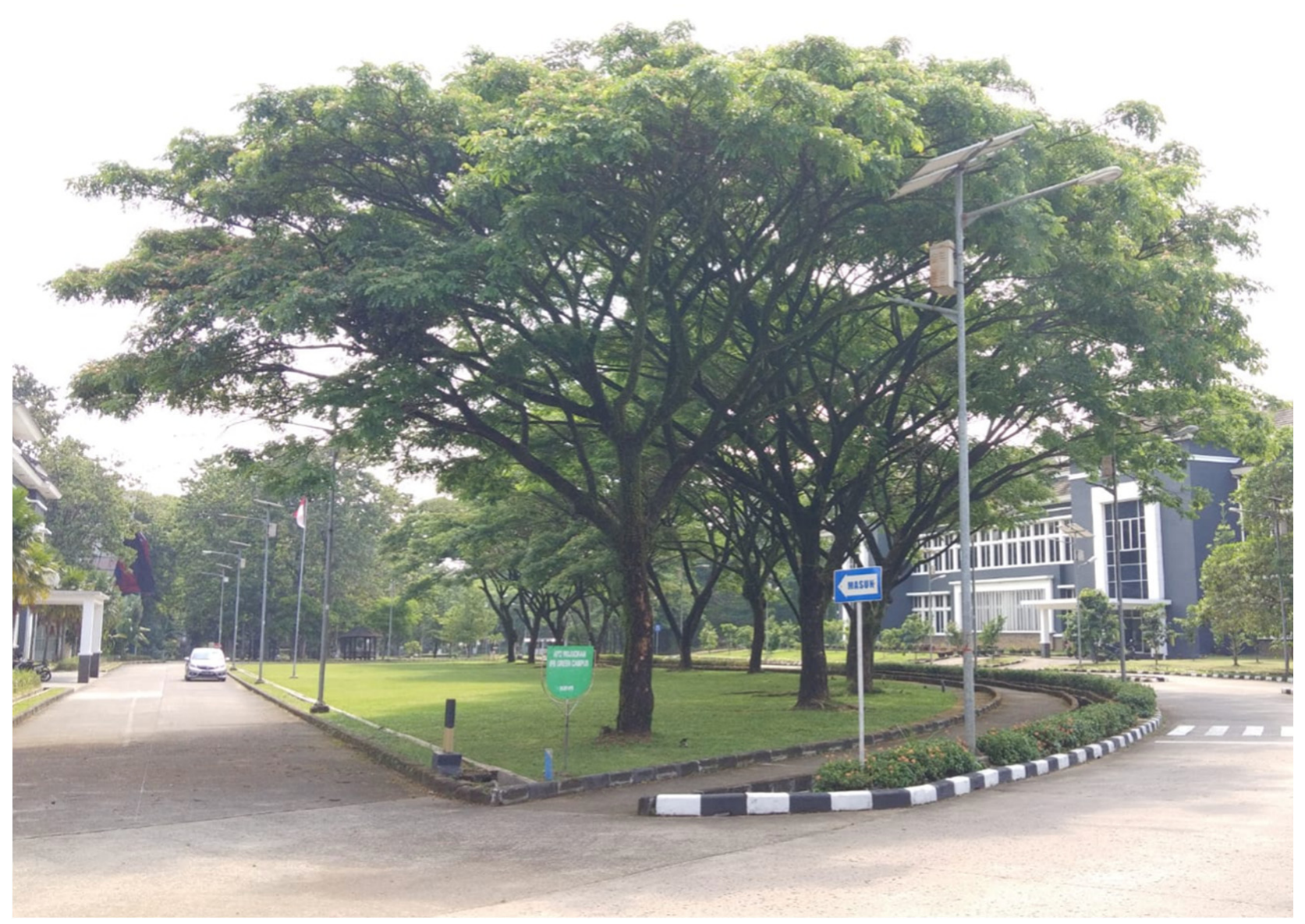

Figure 2. Example of a grove rain trees (Samanea saman) in the study location.

Dynamic elasticity was determined from sound velocity. Sound velocity was the stress wave velocity $(S W V)$ measured in the longitudinal direction on north and west sides of the trunk, using the stress wave timer tool of Fakopp Microsecond Timer (Fakopp Bt, Sopron, Hungary). The measurement was carried out in an area of the tree stem without visible defects, and sensors were placed into the wood, penetrating the bark. The height of the first sensor of the tool, the receiver, was mounted to the stem at $60 \mathrm{~cm}$ above the ground and another sensor, the transmitter, was mounted $100 \mathrm{~cm}$ above the receiver [19]. Sound was generated by hitting the transmitter sensor with a hammer (Figure 3). The sound propagation time was recorded in a reading device, and the sound velocity was calculated as the ratio of the space between the two sensors divided by the propagation time. $S W V$ on standing trees can be used to determine the dynamic modulus of elasticity $(E d)$ of the wood, which has a satisfactory correlation with timber quality $[19,29-31]$. The $E d$ was determined as follows:

$$
E d(\mathrm{GPa})=\mathrm{SWV}^{2} \frac{æ}{\mathrm{~g}}
$$

where $E d$ is in GPa, SWV in $\mathrm{m} \cdot \mathrm{s}^{-1}, \rho$ is wood density $\left(\mathrm{g} \cdot \mathrm{cm}^{-3}\right)$, and $g$ is a gravitational constant $\left(9.81 \mathrm{~m} \cdot \mathrm{s}^{-2}\right)$. Wood density and moisture content were determined based on the ratio of mass to volume and a gravimetry method, respectively, from a small core sample obtained about $5 \mathrm{~cm}$ deep from the bark with a diameter of about $1 \mathrm{~cm}$ and a length of $2 \mathrm{~cm}$ that was extracted from each study tree using an increment core tool. 


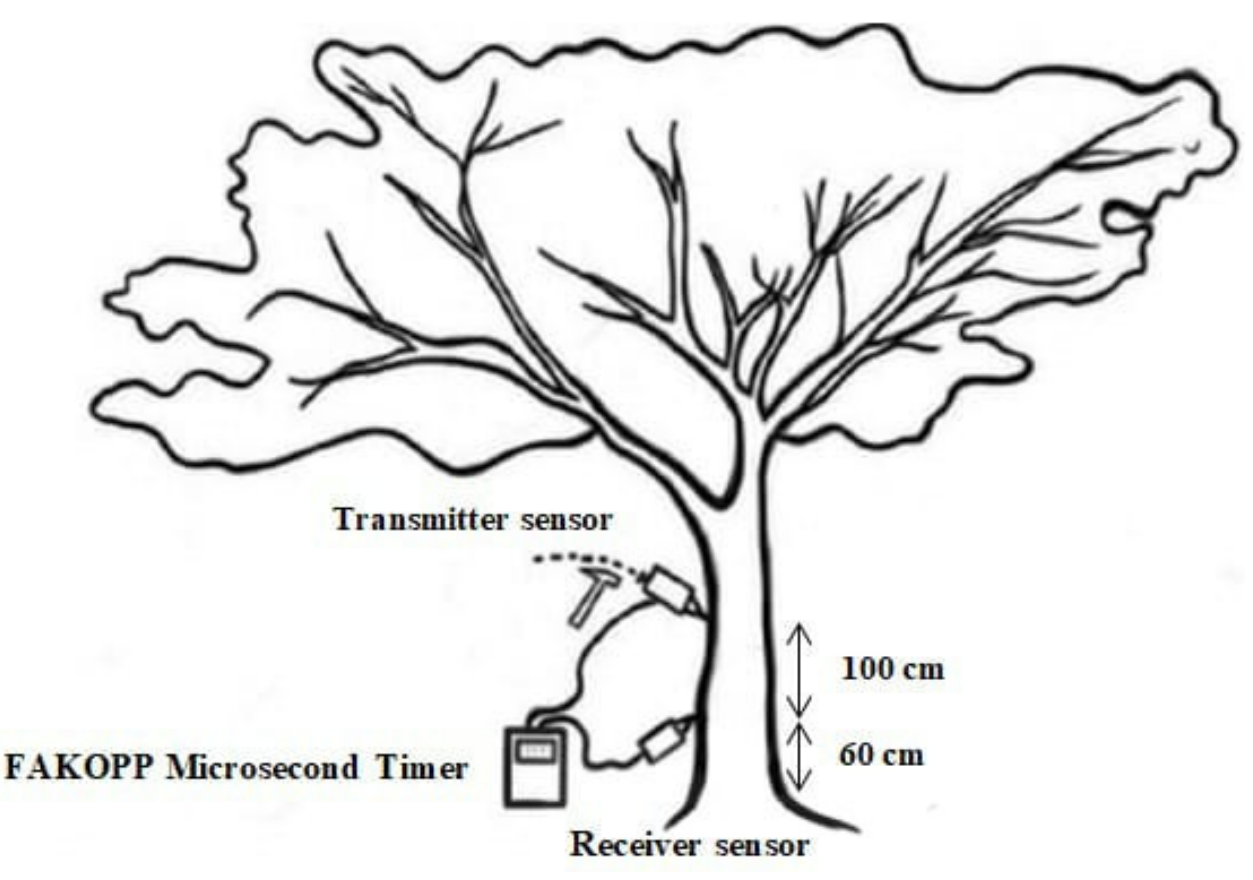

Figure 3. The sketch of the setup for stress wave velocity measurements.

The correlation between the morphometric parameters were analyzed using the canonical correlation. Canonical correlation is a statistical tool to see the correlation between two datasets, i.e., tree growth parameters of $d, h$ and the selected tree morphometric parameters of $h_{c r}, L C R$, slenderness, $D C R$, and PCR. The Pearson's analysis was developed to determine the linear relationship between $S W V$ and $E d$ and all the morphometrics parameters. Basic statistical analysis (e.g., maximum and minimum values, means, standard deviation) and Pearson's analysis were performed with Microsoft Office Excel for Microsoft, while canonical correlation was analyzed using IBM SPSS ${ }^{\circledR}$ Statistics 25.

\section{Results and Discussion}

\subsection{Morphometric Characteristics}

The mean growth and morphometric characteristics of the rain trees are shown in Table 1. Diameter and height of rain trees in our study were $61.40 \mathrm{~cm}$ and $18.80 \mathrm{~m}$, respectively. Live crown ratio $(L C R)$ is the percentage of the total height of the tree that is represented by the live green crown, which is related to the crown length $\left(h_{c r}\right)$. The $L C R$ of individual trees is associated with growth and biomass character [32-34]. LCR is an indicator for the tolerance of the species for site modifications affecting competition for light, and it serves as an indicator of tree vigor [35-37]. The LCR of rain trees in our study was $66.24 \%( \pm 8.97)$ on average. It points out that, in general, the rain trees have high vigor.

In terms of tree health assessment, this variable is important. The crown of a tree consists of the mass of foliage and branches growing outward from the trunk of the tree. The live crown refers to the part of the crown that has live foliage. $L C R$ is considered an indirect measure of a tree's photosynthetic capacity, and it serves as an indicator of a tree's competitive status in the stand. A tree with an LCR of 1.0 (or 100\%) has the maximum possible leaf surface area and biomass, whereas an $L C R$ value closer to zero indicates that a tree's growth is inhibited because of limited leaf surface area [38]. An LCR of 0.33 or higher is optimal for the best growth [39]. Nandika et al. [40] reported classes of LCR that relate to tree vigor: high $(>50 \%)$, moderate $(30-50 \%)$, and low $(<30 \%)$. 
Table 1. Summary of the growth and morphometric characteristic of the rain trees at Darmaga Campus ( $n=50$ trees).

\begin{tabular}{ccccccc}
\hline $\begin{array}{c}\text { Tree Growth and Morphometric } \\
\text { Characteristics }\end{array}$ & Unit & Min & Max & Average & SD & CV \\
\hline Diameter at breast height-dbh $(d)$ & $\mathrm{cm}$ & 35.70 & 116.00 & 61.50 & 18.54 & 0.30 \\
Tree height $(h)$ & $\mathrm{m}$ & 11.50 & 30.00 & 18.80 & 4.09 & 0.22 \\
Crown length $\left(h_{c r}\right)$ & $\mathrm{m}$ & 7.00 & 24.00 & 12.60 & 3.65 & 0.29 \\
Live crown ratio $(L C R)$ & $\%$ & 40.00 & 82.22 & 66.24 & 8.97 & 0.14 \\
Slenderness $(S)$ & - & 18.97 & 50.42 & 32.07 & 7.74 & 0.24 \\
Mean crown diameter $(D C R)$ & $\mathrm{m}$ & 12.18 & 27.97 & 19.86 & 4.42 & 0.22 \\
Horizontal projection of the crown $(P C R)$ & $\mathrm{m}$ & 116.36 & 613.90 & 324.72 & 143.82 & 0.44 \\
\hline
\end{tabular}

Wind has been found to be significant in determining how the thickness of the tree trunk is fundamental to tree stability [41]. The most promising approaches for determining tree and stand stability to windthrow are those that incorporate tree stability characteristics (e.g., the slenderness coefficient) with local stand (e.g., average tree height), site, topography, and windiness features [42,43]. Wang et al. [44] stated that tree susceptibility to wind damage is principally influenced by the slenderness coefficient or taper of the tree. Our study found an average slenderness ratio of 32.07 (Table 1). Onilude and Adesoye [41], Kaźmierczak et al. [45], and Ige [46] indicated that the slenderness coefficient (S) values can be classified into three categories. Specifically, a low slenderness coefficient value $(<70)$ indicates high resistance to wind damage (good stand stability); a moderate value $(70<S<99)$ indicates resistance to high wind velocity, although slight or partial damage may occur; and a high slenderness coefficient $(>99)$ indicates low resistance to windthrow, which can cause damage to trees. For forest trees, a slenderness coefficient below 80 indicates excellent stability [47,48], but for trees in urban areas, lower slenderness ratios of 50:1 have been proposed by [49]. A low slenderness coefficient typically indicates a larger crown, a lower center of gravity, and a better developed root system. Trees with higher slenderness coefficient values (slender trees) are much more susceptible to wind damage. In addition to the tree dimension factor, a study by Ow et al. [13] on rain trees also found that structural soil treatment at a site determines the mechanical stability of trees.

Tree crown size and shape are key variables in the context of the growth space that a tree occupies and the physiological tree functions of the branch dimension and the adaptability to light distribution [6]. The crown widths of woody plant species growing in urban areas are of considerable importance as an overall indicator of health and also serve as an important factor for assessing leaf area and associated ecosystem services, such as carbon sequestration, air pollution removal, air temperature cooling, and rainfall interception [50]. The mean crown diameter $(D C R)$ of rain trees is about $19.86( \pm 4.42) \mathrm{m}$, and the horizontal projection crown $(P C R)$ or crown projection area ranges from 116.36 to $613.90 \mathrm{~m}^{2}$, with a mean of $324.72( \pm 143.82) \mathrm{m}^{2}$. Staples and Elevitch [1] reported that the rain tree has a broad crown diameter that can reach $30 \mathrm{~m}$. The $P C R$ is related to the area covered by the crown of a tree and it can exceed a few hundred square meters [27], which reflects the area occupied by that tree [6]. The higher values of $P C R$ are presumably not only due to the age of the tree, but also seem to be related to the opening area. In terms of a managed area, the opening area provides good light and contributes to greater projection.

\subsection{Relationships between Tree Groth and Morphometric Characteristics}

Table 2 demonstrates the relationships between two data sets of tree growth of tree diameter $(d)$ and height $(h)$ and the morphometric characteristic of tree crown length $\left(h_{c r}\right)$, $L C R$, slenderness, $D C R, P C R$. The table also explained the correlations of the measurement variables to the canonical correlation. There were two dimensions were used in this correlation based on the minimal number of trees charateristics in a data set for the calculation of canonical correlation. The first canonical correlation was 0.9936 . The tree height $(h)$ variable had the largest correlation to the first canonical variable, meaning that $h$ gave the largest influence to tree growth, meanwhile the $h_{c r}$ variable had the largest correlation to 
the first canonical correlation of the morphometrics characteristics. A positive correlation was found in those correlations, meaning that if the $h$ increases, the hcr also increases.

Table 2. The canonical correlation between the tree growth and morphometric characteristics, and the correlations of the variables to the canonical correlation $(n=50)$.

\begin{tabular}{|c|c|c|c|c|c|c|c|c|}
\hline \multirow[t]{2}{*}{ Dim } & \multirow[t]{2}{*}{$\wedge$} & \multicolumn{2}{|c|}{$\begin{array}{l}\text { Tree Growth } \\
\text { Characteristics }\end{array}$} & \multicolumn{5}{|c|}{ Morphometrics Characteristics } \\
\hline & & $d$ & $h$ & $h_{c r}$ & $L C R$ & Slenderness & $D C R$ & PCR \\
\hline 1 & 0.9936 & 0.4618 & 0.9928 & 0.8915 & 0.2372 & 0.3557 & 0.5002 & 0.4888 \\
\hline 2 & 0.9629 & 0.8869 & 0.1197 & 0.0321 & -0.094 & -0.9199 & 0.5675 & 0.5727 \\
\hline
\end{tabular}

Notes: Dim $=$ dimension in canonical relationship; $\hat{\rho}=$ canonical correlation; $d=$ diameter at breast height, $1.3 \mathrm{~m} ; h=$ tree height; $h_{c r}=$ crown length; $L C R=$ live crown ratio; $D C R=$ mean crown length, $P c r=$ horizontal projection crown.

The second canonical correlation was 0.9629 . The diameter $(d)$ had a highest affected with positive correlation at the second canonical component of tree growth, meanwhile the slenderness had a negative correlation to the second canonical component of morphometric characteristics. Those relationships meant that if the $\mathrm{d}$ increases, the slenderness decreases.

Our study in rain trees demonstrated a positive strong relationship between tree length (h) and crown length $\left(h_{c r}\right)$. Meanwhile, a strong negative relationship was found between tree diameter $(d)$ and slenderness. Crown size and shape are key factors in assessing tree growth, and they relate to the physiological function mechanism in terms of the amount of solar radiation intercepted by a tree [6,51]. Troxel et al. [52] reported that shade trees, which are common in urban forests, had a stronger relationship between tree diameter at $\mathrm{dbh}$ and crown diameter $(D C R)$ than ornamental trees which were also found in many various tree species [27,53-55]. Several studies [55-57] mentioned that the linear model demonstrates the best correlation between dbh and crown diameter and height in many tree species in both plantation and urban forests.

\subsection{Dynamic Elasticity of Standing Rain Trees}

The current study found that the wood density of rain trees is about $0.78( \pm 0.06) \mathrm{g} \cdot \mathrm{cm}^{-3}$, with a moisture content of $82.80 \%$ to $370.59 \%$. The average acoustic-stress wave velocity and $E d$ are $2503.12 \mathrm{~m} . \mathrm{s}^{-1}$ and $6.62 \mathrm{GPa}$, respectively, as shown in Table 3. A study by [18] reported the elasticity modulus, $\mathrm{E}_{\mathrm{structure}}$, in the living stem of a rain tree subjected to static bending moment for evaluating tree stability by the pulling test was $6.14 \mathrm{GPa}$. The average wood density was $0.55 \mathrm{~g} \cdot \mathrm{cm}^{-3}$ and the moisture content of core samples was about $75 \%$. Although the approaches for determining the mechanical stiffness properties of standing trees differed between studies, the results obtained were quite close. Tree-pulling experiments allow for an understanding of the relationship between root strength and tree stability. The test is known to overestimate the force required to uproot trees in a consistent manner, and its calculation requires the value of the flexural stiffness of the tree trunk [13,17]. Meanwhile, the acoustic-based test in the longitudinal direction is related to the estimation of tree trunk stiffness and is commonly used to evaluate the mechanical properties of wood for use as a biomaterial [19,21,22]. Our research demonstrates that the acoustic-based tool for measuring stress wave velocity can be an alternative for determining the elasticity modulus of a living stem, a parameter that is usually assessed through pulling tests $[14,17]$. 
Table 3. Average values of wood density, moisture content, stress wave velocity, and dynamic modulus of elasticity (MOE) of standing rain trees $(n=50)$.

\begin{tabular}{ccccccc}
\hline Stem Characteristics $(\boldsymbol{n}=\mathbf{5 0})$ & Unit & Min & Max & Average & SD & CV \\
Wood density $(\rho)$ & $\mathrm{g} \cdot \mathrm{cm}^{-3}$ & 0.60 & 0.88 & 0.78 & 0.06 \\
Moisture content $(M C)$ & $\%$ & 82.80 & 370.59 & 136.55 & 66.75 \\
Stress wave velocity $(S W V)$ & $\mathrm{m} \cdot \mathrm{s}^{-1}$ & 1787.72 & 3334.53 & 2503.12 & 378.74 & 0.49 \\
Dynamic modulus of elasticity $(E d)$ & $\mathrm{GPa}$ & 3.30 & 11.49 & 6.62 & 1.99 & 0.15 \\
\hline
\end{tabular}

A correlation analysis of variables measurement was used to explore the linear relationship between the standing tree acoustic velocity and selected tree morphometric parameters. The obtained results are displayed in Table 4. No relationship was found between acoustic velocity and $E d$ and most morphometric characteristics, and no such correlation was found for tree $L C R$ and slenderness. Both tree $L C R$ and slenderness were weakly correlated with $S W V$ and $E d(r= \pm 0.20)$. In their study, Kranjc et al. [58] found that acoustic velocity was related to tree slenderness $(r=0.42)$ for 490 wood samples of Douglas fir, Norway, and Sitka spruce. Meanwhile, Lindström et al. [59], Searles [60], and Pretzsch and Rais [61] reported that tree slenderness, defined as the ratio of tree height to dbh, is a relatively good predictor of tree stiffness. Our study also demonstrated high multicollinearity in predicting morphometric characteristics in conjunction with acoustic velocity and dynamic $E d$ as reported by [61]. However, the prediction of $E d$ based on acoustic wave velocity for rain trees can be potentially used as variables for tree stability analysis.

Table 4. Perason's correlation for regression analysis of dynamic modulus elasticity and tree morphometric parameter $(n=50)$.

\begin{tabular}{|c|c|c|c|c|c|c|c|c|c|}
\hline & $d$ & $h$ & $h_{c r}$ & $L C R$ & Slenderness & $D C R$ & PCR & $S W V$ & $E d$ \\
\hline$d$ & 1 & & & & & & & & \\
\hline$h$ & 0.565 & 1 & & & & & & & \\
\hline$h_{c r}$ & 0.436 & 0.883 & 1 & & & & & & \\
\hline$L C R$ & 0.029 & 0.223 & 0.645 & 1 & & & & & \\
\hline Slenderness & -0.622 & 0.245 & 0.240 & 0.070 & 1 & & & & \\
\hline$D C R$ & 0.714 & 0.559 & 0.443 & 0.050 & -0.347 & 1 & & & \\
\hline$P C R$ & 0.713 & 0.548 & 0.420 & 0.020 & -0.341 & 0.995 & 1 & & \\
\hline$S W V$ & -0.071 & 0.088 & -0.054 & -0.231 & 0.231 & -0.067 & -0.070 & 1 & \\
\hline$E d$ & -0.081 & 0.082 & -0.056 & -0.229 & 0.234 & -0.068 & -0.071 & 0.997 & 1 \\
\hline
\end{tabular}

\section{Conclusions}

The study was conducted on rain trees that did not undergo intensive maintenance, grew in favorable locations. The tree growth performance showed good vigor and stability based on selected tree morphometry. Statistical analysis showed a strongest positive relationship was found between tree growth parameters of height and crown length; meanwhile, the tree growth of diameter had a strongest negative correlation with tree slenderness. Determining the elastic modulus of living stems is necessary as an important parameter for calculating tree stability that could be done with a simple, handy, and nondestructive tool based on stress wave velocity for practical application by tree manager. The tool has been proven to give satisfactory results equivalent to a common pulling test. The modulus of elasticity of living stems has no relationship with morphometric parameters, except a weak correlation does exist with $L C R$ and tree slenderness. Multicollinearity is found in the relationship between tree morphometry and the mechanical properties of trees assessed with the acoustic-based tool. Further studies are needed to ensure the accuracy of tree responses to different site conditions and species. 
Author Contributions: Conceptualization, drafting, writing, L.K.; review, editing, supervision, L.K., I.Z.S., D.N.; Field and laboratory work, data curation, U.A., T.P. Original draft preparation, U.A., L.K.; Supervision, D.N., N.N.; Formal analysis, U.A., U.D.S. All authors have read and agreed to the published version of the manuscript.

Funding: This research was funded by the Indonesia Ministry of Research and Technology (RISTEK)/National Research and Innovation Agency (BRIN): 8/E1/KPT/2021 and 1/E1/KP.PTNBH/2021.

Data Availability Statement: Not applicable.

Acknowledgments: The authors are grateful for the support of the Indonesia Ministry of Research and Technology (RISTEK)/National Research and Innovation Agency (BRIN) through Research Grants in scheme Fundamental Research, FY 2021.

Conflicts of Interest: The authors declare no conflict of interest.

\section{References}

1. Staples, G.W.; Elevitch, C.R. Samanea Saman (Rain Tree); Species Profiles for Pacific Island Agroforestry; Permanent Agriculture Resources (PAR): Holualoa, HI, USA, 2006.

2. Ow, L.F.; Ghosh, S.; Yusof, M.L.M. Growth of Samanea saman: Estimated Cooling Potential of This Tree in an Urban Environment. Urban For. Urban Green. 2019, 41, 264-271. [CrossRef]

3. Crook, M.J.; Ennos, A.R. The Anchorage Mechanics of Deep-Rooted Larch Larix europea $\times$ japonica. J. Exp. Bot. 1996, 47, 1509-1517. [CrossRef]

4. Brüchert, T.; Baumgart, S.; Bolte, G. Social Determinants of Older Adults' Urban Design Preference: A Cross-Sectional Study. Cities Health 2021, 1-15. [CrossRef]

5. Day, S.D.; Weseman, P.E.; Dickinson, S.B.; Harris, J.R. Contemporary Concepts of Root System Architecture of Urban Trees. Arboric. Urban For. 2010, 36, 149-159. [CrossRef]

6. Pretzsch, H.; Biber, P.; Uhl, E.; Dahlhausen, J.; Rotzer, T.; Caldentey, J.; Koike, T.; Con, T.; Chavanne, A.; Seifert, T.; et al. Crown Size and Growing Space Requirement of Common Tree Species In Urban Centres, Parks, and Forests. Urban For. Urban Green. 2015, 14, 466-479. [CrossRef]

7. De Maria, C.; Bomm, B.F.H.; Nesi, J.; Ho, T.L.; Bobrowski, R. Canopy Architecture and Morphometry of Tree Species Used In The Urban Forest. Floresta 2020, 50, 1892-1901.

8. Bobrowski, R.; Biondi, D. Morfometria De Espécies Florestais Plantadas Nas Calçadas, Revista Da Sociedade Brasileira De Arborização Urbana. Piracicaba 2017, 12, 1-16.

9. Suchoka, M.; Błaszczyk, M.; Juzwiak, A.; Duriasz, J.; Bohdan, A.; Stolarczyk, J. Transit versus Nature. Depreciation of Environmental Values of the Road Alleys. Case Study: Gamerki-Jonkowo, Poland. Sustainability 2019, 11, 1816. [CrossRef]

10. Macfarlane, D.W.; Kane, B. Neighbour Effects on Tree Architecture: Functional Trade-Offs Balancing Crown Competitiveness with Wind Resistance. Funct. Ecol. 2017, 31, 1624-1636. [CrossRef]

11. Peltola, H.M. Mechanical Stability of Trees Under Static Loads. Am. J. Bot. 2006, 93, 1501-1511. [CrossRef]

12. Achim, A.; Ruel, J.C.; Gardiner, B.A.; Laflamme, G.; Meunier, S. Modelling The Vulnerability of Balsam Fir Forests to Wind Damage. For. Ecol. Manag. 2005, 204, 35-50. [CrossRef]

13. Ow, L.F.; Harnas, F.R.; Indrawan, I.G.B.; Sahadewa, A.; Sim, E.K.; Rahardjo, H.; Leong, E.C. Tree-Pulling Experiment: An Analysis into The Mechanical Stability of Rain Trees. Trees 2010, 24, 1007-1015. [CrossRef]

14. Rahardjo, H.; Harnas, F.R.; Indrawana, I.G.B.; Leong, E.C.; Tan, P.Y.; Fong, Y.K.; Ow, L.F. Understanding The Stability of Samanea saman Trees through Tree Pulling, Analytical Calculations and Numerical Models. Urban For. Urban Green. 2014, 13, $355-364$.

15. Niklas, K.J. Tree Biomechanics with Special Reference to Tropical Trees. Tree Physiol. 2016, 6, 414-435.

16. Niklas, K.J. The Elastic Moduli and Mechanics of Populus Tremuloides (Salicaceae) Petioles in Bending and Torsion. Am. J. Bot. 1991, 78, 989-996. [CrossRef]

17. Brüchert, F.; Gero, B.; Speck, T. The Mechanics of Norway Spruce [Picea abies (L.) Karst]: Mechanical Properties of Standing Trees from Different Thinning Regimes. For. Ecol. Manag. 2000, 135, 45-62. [CrossRef]

18. Burcham, D.C.; Autio, W.R.; James, K.; Sadeghi, Y.M.; Kane, B. Effect of Pruning Type and Severity on Vibration Properties and Mass of Senegal Mahogany (Khaya senegalensis) and Rain Tree (Samanea saman). Trees 2019, 34, 213-228. [CrossRef]

19. Wang, X.; Ross, R.J.; McClellan, M.; Barbour, R.J.; Erickson, J.R.; Forsman, J.W.; McGinnis, G.D. Nondestructive Evaluation of Standing Trees With A Stress Wave Method. Wood Fiber Sci. 2001, 33, 522-533.

20. Carson, S.D.; Cown, D.J.; McKinley, R.B.; Moore, J.R. Effects of Site, Silviculture and Seedlot on Wood Density and Estimated Wood Stiffness in Radiata Pine at Mid-Rotation. New Zealand. J. For. Sci. 2014, 44, 26.

21. Madhoushi, M.; Boskabadi, Z. Relationship Between the Dynamic and Static Modulus of Elasticity in Standing Trees and Sawn Lumbers of Paulownia fortune Planted in Iran. Cienc. Y Technol. 2019, 21, 35-44. [CrossRef]

22. Llana, D.F.; Short, I.; Harte, A.M. Use of Non-Destructive Test Methods on Irish Hardwood Standing Trees and Small-Diameter Round Timber For Prediction of Mechanical Properties. Ann. For. Sci. 2020, 77, 1-13. [CrossRef] 
23. Kurnia, I. Study of bird species diversity for the development of birdwatching tourism at IPB Dramaga Campus. Bachelor's Thesis, Faculty of Forestry, IPB University, Bogor, Indonesia, 2003. (In Indonesia).

24. Mubin, N.; Harahap, I.S.; Giyanto. Diversity of Subterranean Termites (Blattodea: Termitoidea) on Various Types Habitat Around IPB University Campus, Bogor, Indonesia. HPT Trop. 2019, 19, 158-169. [CrossRef]

25. Batala, E.; Tsitoni, T. Street Tree Health Assessment System: A Tool for Study of Urban Greenery. Int. J. Sustain. Dev. Plan. 2009, 4, 345-356. [CrossRef]

26. Coombes, A.; Martin, J.; Slater, D. Defining the Allometry of Stem and Crown Diameter of Urban Trees. Urban For. Urban Green. 2019, 44, 126421. [CrossRef]

27. Velsvoski, N.; Andonovski, V.; Vasilevski, K. Research on The Development and Structure of The Crown of Old-Growth Beech Trees on Maleshevski mountains. In Proceedings of the 5th Congress of The Ecologists of Macedonia 2017, Ohrid, North Macedonia, 19-22 October 2016.

28. Krajnc, L.; Farrelly, N.; Harte, A.M. The Influence of Crown and Stem Characteristics on Timber Quality in Softwoods. For. Ecol. Manag. 2019, 435, 8-17. [CrossRef]

29. Legg, M.; Bradley, S. Measurement of Stiffness of Standing Trees and Felled Logs Using Acoustics: A Review. J. Acoust. Soc. Am. 2016, 139, 588-604. [CrossRef]

30. Ross, R.J. Nondestructive Evaluation of Wood; Department of Agriculture, Forest Service: Madison, WI, USA, 2015.

31. Simic, K.; Gendvilas, V.; O’Reilly, C.; Harte, A.M. Predicting Structural Timber Grade-Determining Properties Using Acoustic and Density Measurements on Young Sitka Spruce Trees and Logs. Holzforschung 2019, 73, 139-149. [CrossRef]

32. Adeyemi, A.A.; Jimoh, S.O.; Adesoye, P.O. Crown Ratio Models for Tropical Raindorest Species in Oban Division of The Cross River National Park, Nigeria. J. Agric. Soc. Res. 2013, 13, 63-76.

33. Picard, N.; Saint-Andre, L.; Henry, M. Manual for Building Tree Volume and Biomass Allometric Equations: Form Field Measurement to Prediction; FAO/CIRAD: Paris, France, 2012.

34. Schutz, J.P. The Selection Forest and Other Forms of Structured and Mixed Forests; Parey Buchverlag: Berlin, Germany, 2001.

35. Holdaway, M.R. Modelling Tree Crown Ratio. For. Chron. 1986, 62, 451-455. [CrossRef]

36. Poudel, K.P.; Avery, S.; Granger, J.J. Live Crown Ratio Models for Loblolly Pine (Pinus taeda) with Beta Regression. Forests 2021, 12, 1409. [CrossRef]

37. Hasenauer, H.; Monserud, R.A. A Crown Ratio Model for Austrian forests. For. Ecol. Manag. 1996, 84, 49-60. [CrossRef]

38. Ritchie, M.W.; Hann, D.W. Equations for Predicting Height to Crown Base for Fourteen Tree Species in SW Oregon. Research Paper 50; Forest Research Laboratory, Oregon State University: Corvallis, OR, USA, 1987; p. 14.

39. Zhao, D.; Kane, M.; Borders, B. Crown Ratio and Relative Spacing Relationships for Loblolly Pine Plantations. Open J. For. 2012, 2, 110-115. [CrossRef]

40. Nandika, D.; Kusuma, H.; Kusumawardhani, D.T.; Rumiyati, E.; Tata; Karlinasari, L.; Siregar, I.Z. Health asessment of large and old trees in Ragunan Zoo, Jakarta. IOP Conf. Ser. Mater. Sci. Eng. 2020, 935, 102072. [CrossRef]

41. Onilude, Q.A.; Adesoye, P.O. Relationship Between Tree Slenderness Coefficient and Tree Growth Characteristics of Triplochiton Scleroxylon K.Schum Stands In Ibadan Metropolis. Obeche J. 2007, 25, 6-23.

42. Mattheck, C.; Breloer, H. The Body Language of Trees, A Handbook for Failure Analysis; HMSO, Department of Environment, HMSO Publications Centre: London, UK, 1994; 260p.

43. Navratil, S.; Brace, L.G.; Sauder, E.A.; Lux, S. Silvicultural and Harvesting Options to Favor Immature White Spruce and Aspen Regenerationi in Boreal Mixed Woods; Report; Canadian Forest Service: Northwest Region: Edmonton, AB, Canada, 1994.

44. Wang, Y.; Titus, S.J.; Lemay, V.M. Relationship Between Tree Slenderness Coefficients and Tree or Stand Characteristics for Major species in Boreal Mixed Forest. Can. J. For. Res. 1998, 28, 1171-1183. [CrossRef]

45. Kaźmierczak, K.; Jedraszak, A. The Influence of Crown Length On Tree Stability. Žmogaus Ir Gamt. Sauga 2014, $42-44$.

46. Ige, P.O. Relationship Between Tree Slenderness Coefficient and Tree Or Stand Growth Characteristics For Triplochiton scleroxylon K.Schum stands in Oniganbari forest reserve, Nigeria. J. For. Res. Manag. 2017, 14, 166-180.

47. Kontogiannia, A.; Tsitsonia, T.; Goudelis, G. An index based on silvicultural knowledge for tree stability assessment and improved ecological function in urban ecosystems. Ecol. Eng. 2011, 37, 914-919.

48. Adeyemi, A.A.; Adesoye, P.O. Tree Slenderness Coefficient and Percent Canopy Cover in Oban Group Forest, Nigeria. J. Nat. Sci. Res. 2016, 6, 9-17.

49. Mattheck, C.; Bethge, K.; Kappel, R.; Mueller, P.; Tesari, I. Failure Modes for Trees and Related Criteria. In Proceedings of the International Conference "Wind Effects on Trees", Karlsruhe, Germany, 16-18 September 2003; University of Karlsruhe: Karlsruhe, Germany, 2003; pp. 1-12.

50. Ragula, A.; Chandra, K.K. Tree Species Suitable for Roadside Afforestation and Carbon Sequestration in Bilaspur, India. Carbon Manag. 2020, 11, 369-380. [CrossRef]

51. Buba, T. Relationships Between Stem Diameter at Breast Height (DBH), Tree Height, Crown Length, and Crown Ratio Of Vitellaria Paradoxa CF Gaertn In The Nigerian Guinea Savanna. Afr. J. Biotechnol. 2013, 12, 3441-3446.

52. Troxel, B.; Piana, M.; Ashton, M.S.; Murphy-duning, C. Relationships Between Bole and Crown Size For Young Urban Trees in The Northeastern USA. Urban For. Urban Green. 2013, 12, 144-153. [CrossRef]

53. Monteiro, V.; Doick, K.J.; Handley, P. Allometric relationships for urban trees in Great BritainMadalena. Urban For. Urban Green. 2016, 19, 223-236. [CrossRef] 
54. Dey, T.; Ahmed, S.; Islam, M.A. Relationship of Tree Height-Diameter at Breast Height (DBH) and Crown Diameter- DBH of Acacia auriculiformis Plantation. Asian J. For. 2021, 5, 71-75.

55. Ogana, F.N.; Ercali, I. Modelling Height-Diameter Relationships In Complex Tropical Rain Forest Ecosystems Using Deep Learning Algorithms. J. For. Res. 2021, 1-16. [CrossRef]

56. Stoffberg, G.; van Rooyen, M.; van der Linde, M.; Groeneveld, H. Modeling Dimensional Growth Of Three Street Tree Species In The Urban Forest of The City of Tshwane, South Africa. South. For. 2009, 71, 273-277. [CrossRef]

57. Goelz, J.C.G. Open-Grown Crown Radius of Eleven Bottom-Land Hardwood Species: Prediction and Use in Assessing Stocking. South. J. Appl. For. 1996, 20, 156-161. [CrossRef]

58. Krajnc, L.; Farrelly, N.; Harte, A.M. Evaluating Timber Quality in Larger-Diameter Standing Trees: Rethinking The use of Acoustic Velocity. Holzforsschung 2019, 73, 797-806. [CrossRef]

59. Lindström, H.; Reale, M.; Grekin, M. Using Non-destructive Testing to Assess Modulus of Elasticity of Pinus sylvestris trees. Scand. J. For. Res. 2009, 24, 247-257. [CrossRef]

60. Searles, G. Acoustic Segregation and Structural Timber Production. Ph.D. Thesis, Edinburgh Napier University, Edinburgh, Scotlandb, 2012.

61. Pretzsch, H.; Rais, A. Wood Quality in Complex Forests VersusEven-Aged Monocultures: Review and Perspectives. Wood Sci. Technol. 2016, 50, 1-36. [CrossRef] 